\title{
REMOVAL OF FLUORIDE FROM DRINKING WATER BY USING LOW COST ADSORBENT
}

\author{
Sheetal Bandewar ${ }^{1}$, S. J. Mane ${ }^{2}$, S. N. Tirthakar ${ }^{3}$ \\ ${ }^{1}$ Student, D. Y. Patil College of Engineering, Akurdi \\ ${ }^{2}$ Assistant Professor, D. Y. Patil College of Engineering, Akurdi \\ ${ }^{3}$ Assistant Professor, College of Military Engineering, Pune-31
}

\begin{abstract}
Millions of people rely on drinking water that contains excess fluoride. In fluoride endemic areas, especially small communities with staggered habitat, defluoridation of potable water supply is still a problem. In this study, adsorption potential of granular activated carbon (GAC) from charcoal and coconut shell is investigated for defluoridation of drinking water using continuous fixed bed column. The influence of various operative parameters such as concentration of fluoride, bed height, flow rate, and adsorption capacity of both the adsorbent is carried out.The fluoride removal from synthetic sample is found up to $72 \%$ for fluoride ion concentration of $4 \mathrm{mg} / \mathrm{L}$.
\end{abstract}

Keywords: Adsorption, Defluoridation, fixed bed column study, Granular charcoal, and coconut shell activated carbon.

\section{INTRODUCTION}

Fluoride is known to be a natural contaminant for ground water resources globally. Fluorine, a fairly common element of earth crust, is present in the form of fluorides in a number of minerals and in many rocks [1]. The ingestion of excess fluoride can cause fluorosis which affects the teeth and bones. Moderate amounts lead to dental effects, but longterm ingestion of large amounts can lead to potentially severe skeletalproblems. Paradoxically, low levels of fluoride intake help to prevent dental caries [3].Research of several researchers during the last 5-6 years has proved that life-long impact and accumulation of fluorides cause not only human skeletal and teeth damage, but also changes in the DNA-structure, paralysis of volition, cancer, etc. [2]. Mainly two factors are responsible for contamination of ground water with fluoride:one is geological and second is anthropogenic. Although both geological and manmade sources contribute to the occurrence of fluoride in water, the major contribution comes from geological resources [4]. In the 3rd edition of the World Health Organization (WHO) guidelines on drinking water, it maintains its guideline on the appropriate fluoride concentration at $1.5 \mathrm{mg} / \mathrm{L}$ (WHO 2008). "It is estimated that around 260 million people worldwide (in 30 countries) are drinking water withFluoride content more than $1.0 \mathrm{mg} / \mathrm{L}$. In India alone, endemic Fluorosis is thought to affect around one million people and is a major problem in 17 of the 25states, especially Rajasthan, Andhra Pradesh, Tamil Nadu, Gujarat, and Uttar Pradesh [6]. So Fluoride removal from water is an important mission of Environmental Engineers.

Activated carbon is a good adsorbent to remove fluoride as it has a large surface area and hence a large surface for the adsorption of fluoride. The more will be the surface, the more will be adsorption, and more will be the removal. Activated carbon is usually formed from charcoal. The main raw material used for activated carbon is any organic material with higher carbon content (coal, peat, wood, coconut shells). Granular activated carbon media is commonly produced by grinding the raw material, adding an appropriate binder to give it re-compacting, hardness and crushing to the correct size [11]. The carbon-based material is transformed to activated carbon by thermal decomposition in a furnace by using a controlled heat and atmosphere. The resultant product has an extremely large surface area / volume, and a network of submicroscopic pores where adsorption takes place. The walls of the pores give the surface layer molecules that are essential for adsorption. Remarkably, one pound of carbon (a quart container) gives a surface area equivalent to six football fields [12].

Adsorption is one of the significant techniques in which fluoride adsorbed onto a membrane, or a fixed bed, is packed with resin or other mineral particles [5]. This method is mainly used because it is cost effective, easy to operate and eco-friendly in nature [7]. The technique is also popular due to its availability of a wide range of adsorbent.This paper is an attempt to explore a possibility to utilize waste material adsorbents coconut shell and charcoal to remove fluoride from aqueous solution. The effects of contact time, particle size, GAC dosage and flow rate on fluoride removal are studied.

\section{MATERIALS AND METHODS}

The raw materials, reagents, and preparation method used in experimentation work are discussed below: 


\subsection{Reagents and Chemical Used}

The SPANDS reagent is of AR (Analytical Reagents) grade and procured from Savant Instruments Pvt. Ltd, Hyderabad. Chemical NAF and Charcoal and coconut shell GAC are procured from LOBA Chemie, Mumbai. All chemicals are used as received in all experiment and distilled water is used.

\subsection{Adsorbent}

The coconut shell and charcoal is utilized as adsorbent in the study. Activated carbon of size less than $150 \mathrm{~mm}$ is used for column studies.

\subsection{Preparation of Stock Solution}

Stock solution of fluoride is prepared by dissolving 0.221 $\mathrm{gm}$ of standard sodium fluoride in one liter of distilled water. This stock solution is used to prepare required concentration of fluoride solution.

\subsection{Equipment}

The equipment used to detect fluoride ions is spectrophotometer. (Chemito UV2100)

\subsection{Fixed-Bed Column Studies}

The sorption studies are carried out in a glass column of 2.5 $\mathrm{cm}$ diameter and bed height of $25 \mathrm{~cm}$. Four sets of column study are performed. A glass-wool plug is used in the bottom of the column to support the adsorbent bed and prevent the outflow of particles. In each set, for a given initial fluoride concentrations $(2,4,6$ and $8 \mathrm{mg} / \mathrm{L})$ the downward flow rates are varied and maintained at (2 $\mathrm{ml} / \mathrm{min}, 4 \mathrm{ml} / \mathrm{min}, 6 \mathrm{ml} / \mathrm{min}$, and $8 \mathrm{ml} / \mathrm{min}$ ) corresponding to each of the various concentration values. The GAC of both the material is filled in the glass column in equal amount as $2+2 \mathrm{~cm}, 3+3 \mathrm{~cm}, 4+4 \mathrm{~cm}$. The top of the column is connected to an overhead tank containing the feed solution. The effluent is collected and analyzed for fluoride concentration. Packed bed experiments are carried out at room temperature.

\section{RESULTS AND DISCUSSIONS}

\subsection{Effect of Bed Height}

For optimization of adsorbent depth, the columns are filled with an increment of $2 \mathrm{~cm}$ in all four columns subsequently. The depth which gives maximum removal is the optimum bed depth. Accumulation of $\mathrm{F}$ ion in the fixed bed column is largely dependent on quantity of absorbent inside the column. It is observed that the removal of fluoride ion increases with an increase in the amount of adsorbent up to $6 \mathrm{~cm}$ depth thereafter it shows little decrease or remains constant. In present study the maximum fluoride removal has take place at $6 \mathrm{~cm}$ bed height and results are shown in fig. 1.

\subsection{Effect of Flow Rate}

For optimization of flow rate the optimized bed height $6 \mathrm{~cm}$ is kept constant. Flow rate is adjusted to $2 \mathrm{ml} / \mathrm{min}, 4 \mathrm{ml} / \mathrm{min}$, $6 \mathrm{ml} / \mathrm{min}$, and $8 \mathrm{ml} / \mathrm{min}$ in four columns. The flow rate which gives maximum removal of fluoride ion is the optimum flow rate. It is observed that the removal of fluoride increases with increase in contact time to some extent. Further increase in flow rate does not increase the fluoride removal efficiency. This rapid initial increase in adsorption subsequently gives the way to a very slow approach to equilibrium and saturation is reached at flow rate $4 \mathrm{ml} / \mathrm{min}$. The results are shown in fig. 2.

\subsection{Final Analysis}

Final analysis is carried out by using synthetic sample of $4 \mathrm{mg} / \mathrm{l}$ fluoride concentration and using above optimized parameters i.e. bed depth $=6 \mathrm{~cm}$ and flow rate $=4 \mathrm{ml} / \mathrm{min}$ at normal temperature is kept constant and analyzed over single column. Finally by using both the adsorbent in equal quantity (granular charcoal activated carbon and granular coconut shell activated carbon) proved that it can efficiently remove $72 \%$ of fluoride from drinking water.

Table 1 Fluoride removal efficiency at initial conc. $4 \mathrm{mg} / \mathrm{l}$

\begin{tabular}{|l|l|l|l|l|}
\hline \multirow{2}{*}{$\begin{array}{l}\text { Sr. } \\
\text { No. }\end{array}$} & Flow & Rate & $\begin{array}{l}\text { Adsorbent } \\
\text { dose }\end{array}$ & $\begin{array}{l}\text { Initial Conc.= } \\
\mathrm{mg} / \mathrm{l}\end{array}$ \\
\cline { 4 - 5 } & $\begin{array}{l}\text { Removal } \\
\mathrm{mg} / \mathrm{l}\end{array}$ & $\begin{array}{l}\text { Efficiency } \\
\%\end{array}$ \\
\hline 1 & $2 \mathrm{ml} / \mathrm{min}$ & $3 \mathrm{~cm}+3 \mathrm{~cm}$ & 1.09 & 26.39 \\
\hline 2 & $4 \mathrm{ml} / \mathrm{min}$ & $3 \mathrm{~cm}+3 \mathrm{~cm}$ & 1.89 & 45.76 \\
\hline 3 & $6 \mathrm{ml} / \mathrm{min}$ & $3 \mathrm{~cm}+3 \mathrm{~cm}$ & 2.97 & 71.91 \\
\hline 4 & $8 \mathrm{ml} / \mathrm{min}$ & $3 \mathrm{~cm}+3 \mathrm{~cm}$ & 2.85 & 69.01 \\
\hline
\end{tabular}

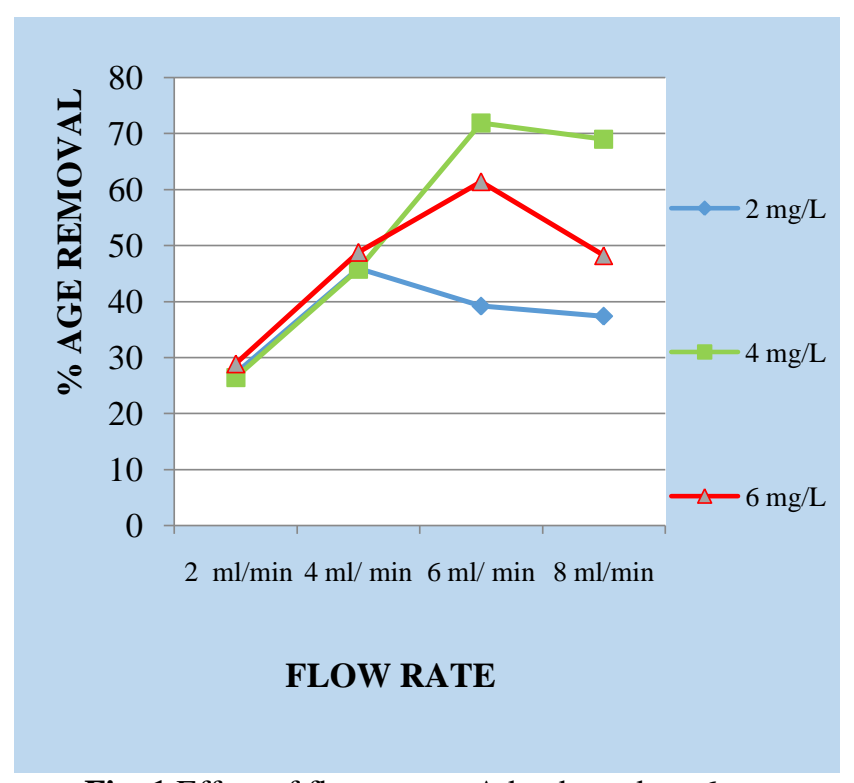

Fig. 1 Effect of flow rate at Adsorbent dose $6 \mathrm{~cm}$ 
Table 2 Fluoride removal efficiency at varying adsorbent dose and flow rate

\begin{tabular}{|l|l|l|l|l|}
\hline \multirow{2}{*}{$\begin{array}{l}\text { Sr. } \\
\text { No. }\end{array}$} & \multirow{2}{*}{\begin{tabular}{l} 
Rlow \\
\multicolumn{2}{|l|}{}
\end{tabular}} & \multicolumn{4}{|l|}{ Adsorbent dose } \\
\cline { 3 - 5 } & $\begin{array}{l}2 \mathrm{~cm}+ \\
2 \mathrm{~cm}\end{array}$ & $\begin{array}{l}3 \mathrm{~cm}+ \\
3 \mathrm{~cm}\end{array}$ & $4 \mathrm{~cm}+4 \mathrm{~cm}$ \\
\hline 1 & $2 \mathrm{ml} / \mathrm{min}$ & 34.87 & 26.39 & 23.92 \\
\hline 2 & $4 \mathrm{ml} / \mathrm{min}$ & 38.60 & 44.76 & 44.27 \\
\hline 3 & $6 \mathrm{ml} / \mathrm{min}$ & 43.64 & 71.91 & 60.81 \\
\hline 4 & $8 \mathrm{ml} / \mathrm{min}$ & 45.18 & 69.01 & 57.51 \\
\hline
\end{tabular}

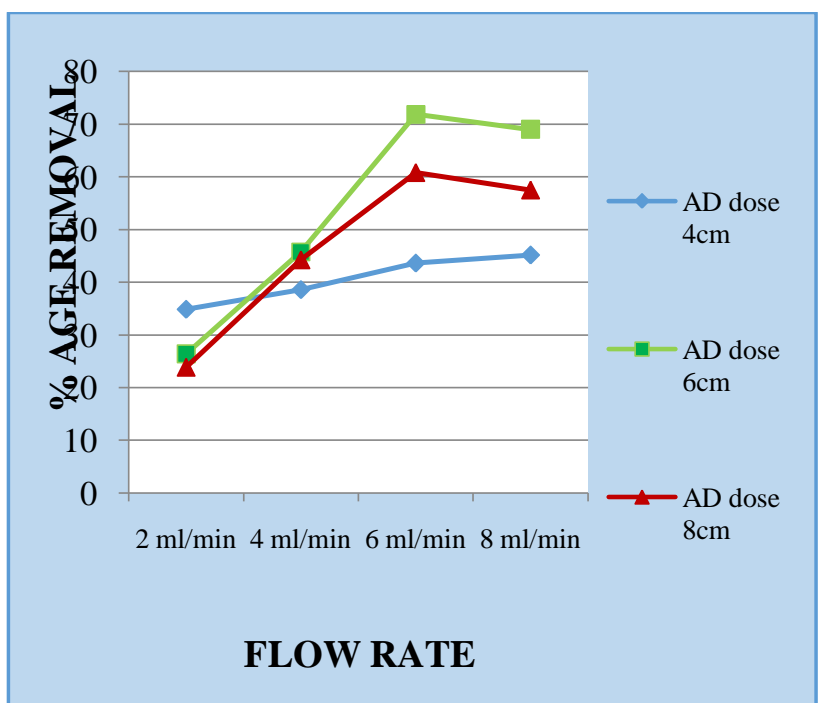

Fig. 2 Effect of adsorbent dose at initial concentration of 4 $\mathrm{mg} / \mathrm{L}$

\section{CONCLUSION}

Maximum fluoride removal from synthetic solution is found to be $72 \%$ by using granular charcoal and coconut shell activated carbon. Percentage removal is different for different fluoride concentrations best removal is observed at fluoride concentration of $\quad 4 \mathrm{mg} / \mathrm{l}$ and adsorbent dose of $6 \mathrm{~cm}$ at $4 \mathrm{ml} / \mathrm{min}$ flow rate.

\section{REFERENCES}

[1] Chidambaram, S. Ramanathan, Vasudevan S, Fluoride removal studies in water using natural material. Water, air and soil pollution, 29, p. 0378473, 2001..

[2] Veressinina Y., Trapido M., Ahelik V., and Munter R., Fluoride in drinking water: The problem and its possible solution. Proc. Estonian Acad. Sci. Chem., 50(2), P. 81-88, 2001.

[3] SEHN, P. Fluoride removal with extra low energy reverse osmosis membranes: three years of large scale field experience in Finland. Desalination, 223, p. 73-84,2008.
[4] NATH, S.K. and DUTTA, R.K. Fluoride removal from water using crushed limestone, Indian Journal Chemical Technology, 17, p. 120-125, 2010.

[5] ALAGUMUTHU, G. and RAJAN, M.Equilibrium and kinetics of adsorption of fluoride onto zirconium impregnated cashew nut shell carbon. Chem. Eng. J., 158, p. 451-457, 2010.

[6] VARDHAN, C.M.V. and KARTHIKEYAN, J.2011. Removal of Fluoride from Water Using Low-Cost Materials. Fifteenth International Water Technology Conference, IWTC-15, Alexandria, Egypt,2011.

[7] Chen N., Z. Zhang, C. Feng, investigation on the batch and fixed bed column performance of fluoride adsorption by Kanuma mud. Desalination, 286, 7682, 2011.

[8] D.S. Bhargava, Economical technology of fluoride removal using fishbone charcoal columns at domestic level, $2^{\text {nd }}$ international workshop on fluorosis prevention and defluoridation of water, p. 118-122, 2011.

[9] P. B. Bhagwati, C. B. Shivayogimath, M. N. Hiremath, Column investigation of fluoride on activated carbon prepared from Almond shell, IJPHE, vol. 2012-13,July 2012.

[10] Sonila Awasthi, S. K. Gupta, Defluoridation of sub soil water by using Ground nut husk carbon, Water, and wastewater: perspectives of developing countries, 1075-1079.

[11] B. Saha, M. H. Tai, M. Streat, Process safety and environmental protection Volume 79, 211-217,2 001.

[12] Jasmin Kaur, Haripada Bhunia, Removal of fluoride from drinking water by activated carbon, VSRD international journal of technical and non-technical research, Vol. IV, Issue VIII, August 2013. 